\title{
Complex effects of non-host diversity on the removal of free-living infective stages of parasites
}

\author{
Jennifer Welsh ${ }^{1}$, Mirjana Markovic ${ }^{1}$, David Thieltges ${ }^{2}$, and Jaap van der Meer ${ }^{3}$ \\ ${ }^{1} \mathrm{NIOZ}$ \\ ${ }^{2}$ Royal Netherlands Institute for Sea Research \\ ${ }^{3}$ Wageningen University and Research Wageningen Marine Research
}

December 9, 2020

\begin{abstract}
Ecological communities can affect transmission pathways of parasites and pathogens, ultimately affecting disease dynamics. While the community composition of less competent decoy hosts is known to affect diseases in focal hosts, it remains poorly understood whether such diversity effects also exist when non-host organisms remove free-living parasite stages, e.g. by predation. In response surface design laboratory experiments, we investigated non-host diversity effects on the removal of cercarial stages of trematodes, ubiquitous parasites in aquatic ecosystems. In all three combinations of two non-hosts at four density levels, the addition of a second non-host did not generally result in increased parasite removal but neutralised, amplified or reduced the parasite removal exerted by the first non-host, depending on the density. These complex non-host diversity effects were probably driven by intra- and interspecific interactions and suggest the need to integrate non-host diversity effects in understanding the links between community diversity and disease risk.
\end{abstract}

\section{Hosted file}

Title_Page_Welsh_et_al_Complex_effects_of_non-host_diversity.pdf available at https : //authorea.com/users/382017/articles/497962-complex-effects-of-non-host-diversity-onthe-removal-of-free-living-infective-stages-of-parasites 


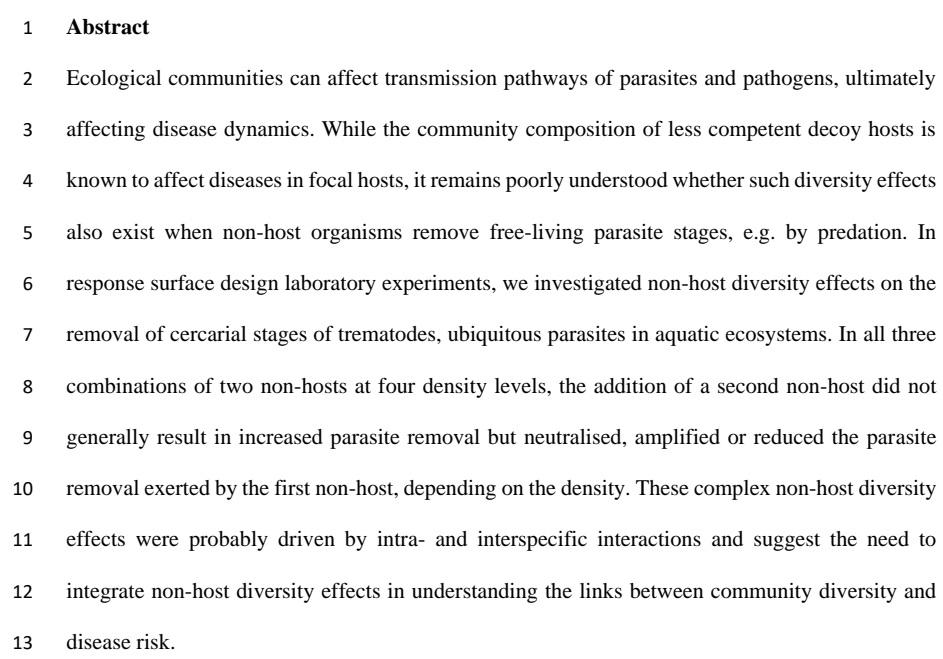

14

\section{Hosted file}

Manuscript_Welsh_et_al_Complex_effects_of_non-host_diversity.pdf available at https: //authorea.com/users/382017/articles/497962-complex-effects-of-non-host-diversity-onthe-removal-of-free-living-infective-stages-of-parasites

\section{Hosted file}

References_Welsh_et_al_Complex_effects_of_non-host_diversity.pdf available at https: //authorea.com/users/382017/articles/497962-complex-effects-of-non-host-diversity-onthe-removal-of-free-living-infective-stages-of-parasites 
1 Table 1: Model selection results, showing the degrees of freedom (df) and deviances for each model from the most complex (model 1)

2 to the simplest model (model 5) for each non-host species combination. The best model in all three cases was the most complex model

3 which included densities of the first non-host species $\left(\mathrm{X}_{1}\right)$, densities of the second non-host species $\left(\mathrm{X}_{2}\right)$ and the interaction $\left(\mathrm{X}_{1}: \mathrm{X}_{2}\right)$

4 between the two non-hosts species. The dispersion factor $(\phi)$ for the best-fitting model for each non-host species combination is

5 shown. For details of model selection procedures see text and Fig. S1.

\begin{tabular}{cccccc}
\hline Model code & Model & df & \multicolumn{3}{c}{$\begin{array}{c}\text { Deviance } \\
\text { Crabs \& seaweed }\end{array}$} \\
\hline 1 & $\mathrm{X}_{1}+\mathrm{X}_{2}+\mathrm{X}_{1} \mathrm{X}_{2}$ & 48 & 130.7 & 840.1 & 183.1 \\
2 & $\mathrm{X}_{1}+\mathrm{X}_{2}$ & 57 & 306 & 1034.7 & 638.8 \\
3 & $\mathrm{X}_{1}$ & 60 & 615.3 & 1873.3 & 683.4 \\
4 & $\mathrm{X}_{2}$ & 60 & 1090.3 & 1232.3 & 1302 \\
5 & 1 & 63 & 1373.9 & 1930.5 & 1355.5
\end{tabular}

7

\begin{tabular}{llll}
$\phi$ from best fitting model & 2.72 & 17.5 & 3.81 \\
\hline
\end{tabular}




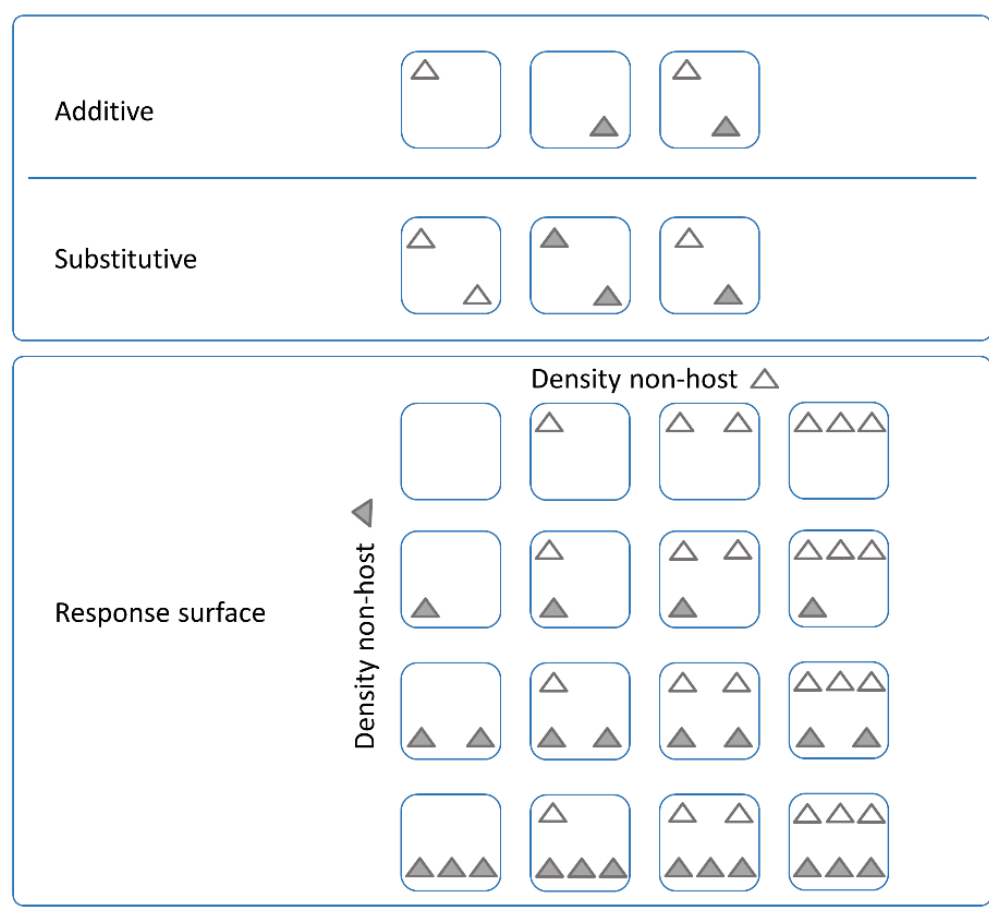



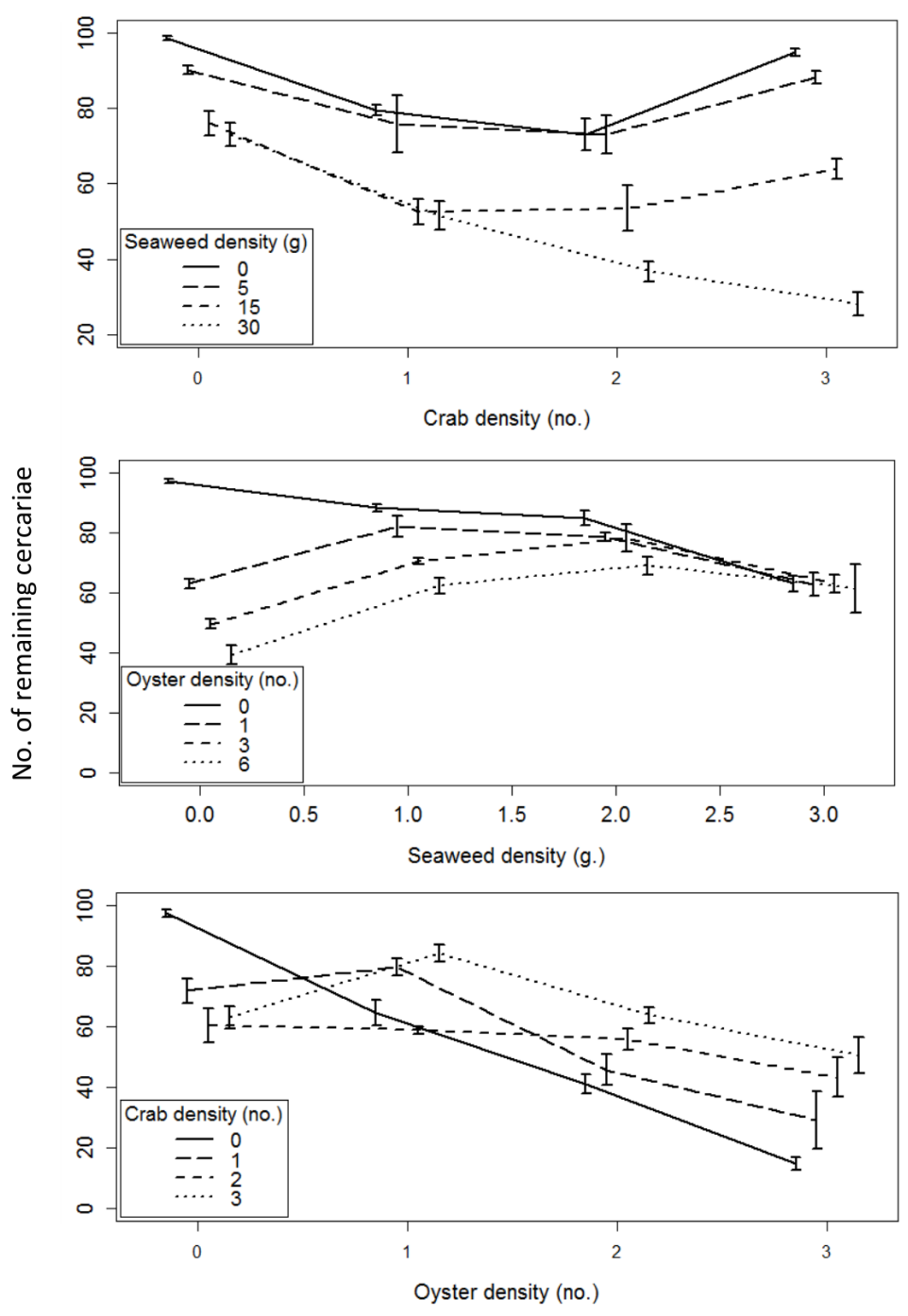